\title{
Arbitrarily Primed PCR To Type Vibrio spp. Pathogenic for Shrimp
}

\author{
CYRILLE GOARANT, ${ }^{1}$ FABRICE MERIEN,${ }^{2}$ FRANCK BERTHE,${ }^{3}$ ISABELLE MERMOUD ${ }^{4}$ \\ ANI PHILIPPE PEROLAT ${ }^{2 *}$ \\ Laboratoire de Recherche Aquacole IFREMER en Nouvelle-Calédonie, Station d'Aquaculture de Saint Vincent, 98846 \\ Nouméa Cedex, ${ }^{1}$ and Laboratoire des Leptospires, Institut Pasteur de Nouvelle-Calédonie, ${ }^{2}$ and CIRAD/EMVT, \\ Programme Elevage, ${ }^{4} 98845$ Nouméa Cedex, New Caledonia, and Laboratoire Biologie et Ecologie des Invertébrés \\ Marins, IFREMER Station de La Tremblade, Ronce les Bains, 17390 La Tremblade, France ${ }^{3}$
}

Received 9 February 1998/Accepted 4 January 1999

\begin{abstract}
A molecular typing study on Vibrio strains implicated in shrimp disease outbreaks in New Caledonia and Japan was conducted by using AP-PCR (arbitrarily primed PCR). It allowed rapid identification of isolates at the genospecies level and studies of infraspecific population structures of epidemiological interest. Clusters identified within the species Vibrio penaeicida were related to their area of origin, allowing discrimination between Japanese and New Caledonian isolates, as well as between those from two different bays in New Caledonia separated by only $50 \mathrm{~km}$. Other subclusters of New Caledonian $V$. penaeicida isolates could be identified, but it was not possible to link those differences to accurate epidemiological features. This contribution of AP-PCR to the study of vibriosis in penaeid shrimps demonstrates its high discriminating power and the relevance of the epidemiological information provided. This approach would contribute to better knowledge of the ecology of Vibrio spp. and their implication in shrimp disease in aquaculture.
\end{abstract}

Vibriosis is a major disease problem in shrimp aquaculture, causing high mortality and severe economic loss in all producing countries $(5,17,21)$. Vibrio spp. are most often considered opportunistic pathogens in shrimp, but primary disease caused by highly virulent strains has also been reported $(9,13,27)$. On the basis of phenotypic data, the major species causing vibriosis in shrimp are Vibrio alginolyticus, $V$. anguillarum, $V$. harveyi, and $V$. parahaemolyticus $(14,17,18)$.

In New Caledonia (South Pacific), shrimp aquaculture is based on the complete cycle of Penaeus stylirostris in a semiintensive farming system in earthen ponds. Located between latitudes $19^{\circ} \mathrm{S}$ and $23^{\circ} \mathrm{S}$, New Caledonia has a tropical oceanic climate with a hot season from mid-November to mid-April. The average minimum and maximum morning water temperatures in shrimp ponds are $20.5^{\circ} \mathrm{C}$ in July and $28.2^{\circ} \mathrm{C}$ in February. Since 1993 , shrimp farms have been affected by a disease, named syndrome 93, causing mass mortality with a significant decrease in yields and survival rates. Mortality episodes frequently occur during the southern winter, from mid-May to mid-September. Moribund prawns display a wide spectrum of clinical signs, including disoriented swimming, lethargy, weakness, and abnormal coloration of the body and appendages. High numbers of bacteria belonging to the genus Vibrio are systematically isolated from diseased shrimp hemolymph, revealing bacterial septicemia (20). Based on phenotypic and genotypic studies (ribotyping and DNA-DNA hybridization) (6), the species involved in syndrome 93 belong to the genospecies $V$. alginolyticus, $V$. harveyi, $V$. nigripulchritudo, and $V$. penaeicida. Since 1994, V. penaeicida and $V$. nigripulchritudo were the most frequently isolated, and their high pathogenicity was demonstrated in an in vivo experimental infection system in P. stylirostris (11).

Phenotype-based identification of marine bacteria relies on

* Corresponding author. Present address: Institute Pasteur, BP 61, 98845 Nouméa, New Caledonia. Phone: 6872702 80. Fax: 6872733 90. E-mail: perolat.pasteur@canl.nc. time-consuming techniques that have limited discriminating power $(1,2)$. The current genomic approaches used for the identification and the typing of Vibrio strains, such as DNADNA hybridization and ribotyping $(1,13,23)$, are useful for taxonomic studies and identification to the subspecies level. However, reliable tools for strain differentiation are essential for studying epidemiology and pathogenicity. Arbitrarily primed PCR (AP-PCR) generates fingerprints that can be used to compare microorganisms at the species level and within a species with high discriminating power $(30,31)$. This method, which has successfully been applied to numerous bacterial species and strains $(19,24,25,32)$, is very reliable, docs not require any previous knowledge of DNA sequences in the genome to be analyzed, and needs much less DNA than current molecular genotyping methods. The purpose of this study was to characterize and differentiate the Vibrio isolates involved in syndrome 93 by using fingerprints obtained with AP-PCR with regard to their geographic origins and the zootechnical practices used at the corresponding shrimp farms.

\section{MATERIALS AND METHODS}

Bacterial strains. Both reference strains and wild-type isolates were cultured in accordance with standard procedures (1).

(i) Reference strains. Four type strains, from the collection of the Pasteur Institute (Paris, France), representing the major species previously identified in syndrome 93 mortality outbreaks were included in this study (Table 1): $V$. penacicida KH-1 ${ }^{1}$ (which was isolated from t'enaens jopomicus in Japan), V. alginolyticus CIP $103336^{11}$ (= ATCC 17749), V. hancyi CIP 103192' (= ATCC 14126 ), and V. nignipulchriudo CIP $103192^{1}$ (= ATCC 27043).

(ii) Wild-type isolates. Fifty-three field isolates from Now Caledonia were selected as representative of the strains involved in outbreaks of vibriosis (syndrome 93) from January 1994 to June 1995 (Table 1). Forty-five were isolated from diseased shrimp during three mortality peaks that occurred between March and June 1995 in four different shrimp farms (Fig. 1). The eight remaining strains are representative of previous outbreaks. In order to compare pathogenic $V$ penaeicida isolates from New Caledonia with others field strains, three Japanese $V$. penacicida strains (KO-1. KT-1, and PD-A) isolated from diseased $P$. japonicus shrimp were included in the studied set. New Caledonian field strains were isolated from hemolymph of diseased shrimp with vibriosis as the only or major morphotype. A single strain was conserved for each individual shrimp. All of the strains were isolated on Marine Agar 2216F (Difco Laboratories. Detroit Mich.), except strain F14 (TCBS Agar; Difco). Identification to the species level 
TABLE 1. Vibrio sp. reference strains and field isolates used in the present study

$\begin{gathered}\text { Organism or source and isolate } \\ \text { name, isolation date, }{ }^{a} \text { and origin }\end{gathered}$
Reference strains
V. alginolyticus CIP $103336^{\text {Ih }}$
V. hanveyi CIP $103192^{\mathrm{T}}$
V. nigripulchritudo CIP $103195^{1}$
V. penaeicida $\mathrm{KH}-1^{\mathrm{T}}$
Japanese field strains
V. penaeicida KO-1, 1986, Japan
V. penaeicida KT-1, 1986, Japan
V. penaeicida $\mathrm{PD}-\mathrm{A}, 1986$, Japan

New Caledonian field strains

Aquamon farm

AQ61;" March 1994, NC

AQ66,' March 1994, NC

AQ102, June 1995, NC

AQ103, June 1995, NC

AQ104, June 1995, NC

AQ105, June 1995, NC

AQ106, June 1995, NC

AQ107, June 1995, NC

AQ109, June 1995, NC

AQ110, June 1995, NC

AQ111, June 1995, NC

AQ112, June 1995, NC

AQ113, June 1995, NC

AQ114, June 1995, NC

Identification

Aquamer farm

AM23, October 1994, NC

AM101, May 1995, NC

AM102, May 1995, NC

AM107, May 1995, NC

AM108, May 1995, NC

AM109, May 1995, NC

AM111, May 1995, NC

AM112, May 1995, NC

AM113, May 1995, NC

AM114, May 1995, NC

AM115, May 1995, NC

AM116, May 1995, NC

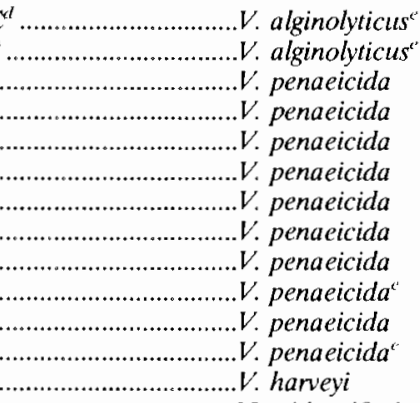

...Not identified

FAO farm

F1, May 1995, NC

F2, May 1995, NC

F5, May 1995, NC

F6, May 1995, NC

V. penaeicida

$V$. penaeicida

V. nigripulchritudo

$V$. penaeicida

V. penaeicida

V. nigripulchritudo

$V$. penaeicida

V. penaeicida

V. penaeicida

.. nigripulchritudo

.V. nigripulchritudo

V. penaeicida

F11, May 1995, NC

V. penaeicida

V. penaeicida

V. penaeicida

$V$. penaeicida

NC penaeicida

F15, May 1995, NC................................. penaeicida

F24, May 1995, NC......................................... penaeicida

F25, May 1995, NC......................................... penaeicida

Sea Farm

SF5, January 1994, NC................................ alginolyticus

SF100, March 1995, NC .................................... penaeicida

SF101, March 1995, NC ................................... penaeicida

SF113, March 1995, NC................................. penaeicida

SF116, March 1995, NC ............................... . penaeicida

SF121, March 1995, NC................................ penaeicida

SF122, March 1995, NC ...................... $V$ penaeicida

$\underline{\mathrm{SF} 125}$, March 1995, NC.................................. penaeicida

$\overline{\mathrm{SF}} 126$, March 1995, NC .................................... penaeicida

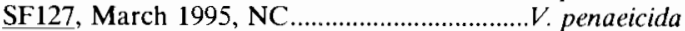

TABLE 1-Continued

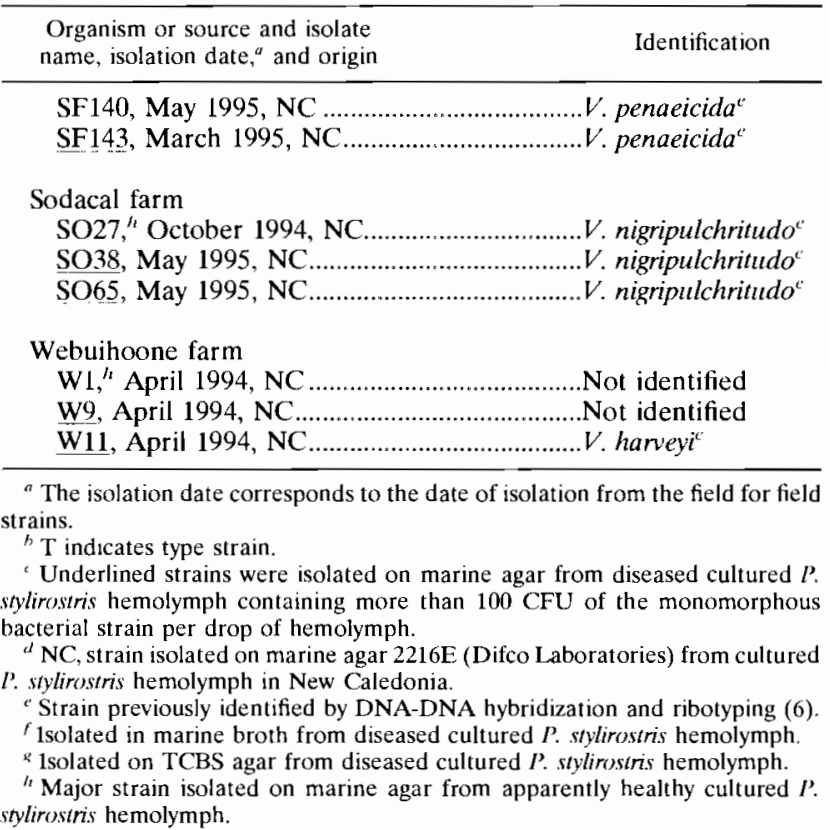

was done by using phenotyping tests (Biotype 100, Api System; BioMérieux, Marcy l'Etoile, France). In addition, selected strains (Table 1) were subjected to DNA-DNA hybridization and ribotyping in a parallel taxonomic study (6).

Geographical and zootechnical data. The shrimp farms included in the study are located on the southwest coast of New Caledonia (Fig 1) Aquamon (AO isolates), FAO ( $\mathrm{F}$ isolates), and Sea Farm ( $\mathrm{SF}$ isolates) are located on Saint Vincent Bay. Sodacal (SO isolates) and Aquamer (AM isolates) are located on Moindou Bay, $50 \mathrm{~km}$ north of Saint Vincent Bay. Webuihoone (W isolates) is located $150 \mathrm{~km}$ north of Moindou Bay. Aquamer is located at the Moindou estuary; there is evidence that it recycles some of the outlet water from Sodacal, as well as its own. Postlarvae stocked in the ponds originate from two separate hatcheries. Aquamer and Sodacal usually stock postlarvae from the Mara hatchery, located close to Sodacal on Moindou Bay, whereas Aquamon, FAO, and Sea Farm usually stock postlarvae from the Montagnes hatchery, located near Aquamon on Saint Vincent Bay, but there are many transfers of postlarvae between

$\stackrel{B}{3}$

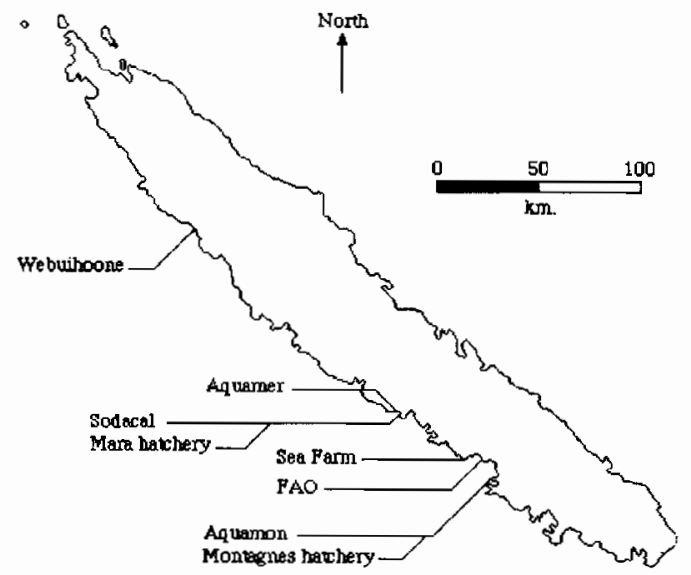

FIG. 1. Schematic map of New Caledonia showing the locations of the shrimp farms and hatcheries discussed in this report. 
these two bays. A preliminary field survey did not find either $V$. penaeicida or $V$. nignpulchritudo strains in any postlarval stock.

Extraction of bacterial genomic DNAs. Vibrio strains were cultured in tryptsc soy broth (BioMéricux) supplemented with $2 \% \mathrm{NaCl}$ (Sigma Chemical Co., St. Louis, $\mathrm{Mo}$.) at $30^{\circ} \mathrm{C}$ with cont inuous shaking until the stationary phase of growth was reached. DNAs were extracted and purified by two different methods. (i) Cultures $(50 \mathrm{ml})$ were harvested by centrifugation at $10,000 \times g$ for $10 \mathrm{~min}$. The resultant pellets were lysed with a $1 \%$ sodium dodecyl sulfate (SDS) $-1-\mathrm{mg} \cdot \mathrm{ml}^{-1}$ proteinase $\mathrm{K}$ solution, and the bacterial nucleic acids were extracted by a phenolchloroform-isoamyl alcohol (25:24:1, vol/vol/vol) mixture as described by Brenner et al. (4). Extracted DNAs were resuspended in $1 \times$ Tris-EDTA buffer. (ii) DNAs were also extracted by using silica particles and guanidinium isothiocyanate lysis buffer in aecordance with the 2-h method described by Boom et al. (3) from small culture aliquots ( 3 to $5 \mathrm{ml}$ ).

AP-PCR. Fingerprinting was performed as described previously (30), with minor modifieations. Primers KF (5'-CACACGCACACGGAAGAA-3'), KN (5'-CCTTGCGCGCATGTACATGG-3'), RSP (5'-GGAAACAGCTATGACC ATGA-3'), KZ (5'-CCCATGTGTACGCGTGTGGG-3'), KpnR (5'-CCAAGT CGACATGGCACR'TGTATACATAYGTAAC-3'), KG (5'-CACACGCACAC GGAAGAA- $\left.3^{\prime}\right)$, and SP (5'-TTGTAAAACGACGGCCAG-3') were purchased from Genset (Paris. France). Fifty-microliter reaction mixtures were prepared with $100 \mathrm{ng}$ of DNA-1 $\times$ Tay polymerase buffer $\left(100 \mathrm{mM}\right.$ Tris $\left[\mathrm{pH} 8.3,20^{\circ} \mathrm{C}\right.$, 500 $\mathrm{mM} \mathrm{KCl}-\mathrm{MgCl}_{2}-0.2 \mathrm{mM}$ each deoxynucleoside triphosphate (Boehringer Mannheim, Germany) $-1 \mu \mathrm{M}$ single oligonucleotide prime $\mathrm{r}-5 \mu \mathrm{Ci}$ of $\left[{ }^{32} \mathrm{P}\right] \mathrm{dCTP}$ (3,000 Ci/mmol; Amersham International, Amersham, England) $-1.25 \mathrm{U}$ of $\mathrm{Taq}$ polymerase (Amersham).

Amplification reactions were cycled twice in a 96-well GeneAmp 9600 thermocycler (Perkin-Elmer) through a low-stringeney temperature profile and then 40 times through a high-stringency temperature profile as previously described (24). Five microliters of each reaction mixture was combined with $15 \mu \mathrm{l}$ of $98 \%$ formamide dye and heated to $68^{\circ} \mathrm{C}$ for $15 \mathrm{~min} ; 5 \mu \mathrm{l}$ of each sample was loaded onto a $4 \%$ acrylamide $-50 \%$ urea sequencing gel with $1 \times$ TBE $(90 \mathrm{mM}$ Trisborate. $2 \mathrm{mM}$ EDTA), and electrophoresis was performed at $400 \mathrm{~V}$ overnight until the xylene cyanol tracking dye was approximately $10 \mathrm{em}$ from the bottom. pUCBM21 DNA digested by HpaII plus pUCBM2I DNA digested by IraI and HindIII (Boehringer), pBR328 DNA digested by RgII and HinfI (Boehringer), and pBR322 DNA digested by MspI (New England Biolabs) were used as molecular size markers. The gel was autoradiographied for 24 to $72 \mathrm{~h}$ on Kodak $\mathrm{X}$-Omat X-ray film. Amplieon molecular size was determined by interpolation of the distances of migration (12) of molecular size markers and AP-PCR products. In accordance with Welsh and McClelland (30), only major bands were considered in the analysis as share-derived eharacters, and this allowed the construction of a key for type grouping of the strains according to the amplicons produced with a given primer (see Table 2 ).

In order to select primers producing more polymorphism, a first screentng of AP-PCR products without $\left[{ }^{32} \mathrm{P}\right] \mathrm{dCTP}$ was performed by using electrophoresis on a $2 \%$ agarose gel (NuSieve 3:1, FMC, Rockland, Maine) with $0.5 \times$ TBE buffer $(3 \mathrm{~V} / \mathrm{cm}$ for $16 \mathrm{~h})$, followed by ethidium bromide staining.

\section{RESULTS}

Primer selection. On the basis of the fingerprints observed on agarose gel, three (RSP, KF, and SP) of the seven primers tested were selected for accurate study with acrylamide-urea sequencing gel.

DNA extraction techniques and reliability. The fingerprints obtained by AP-PCR using the two different techniques of DNA extraction were identical. The only differences, sporadically observed, were due to insufficient quantities of genomic DNA in the amplification mixture, i.e., 50 instead of $100 \mathrm{ng}$. These variations affected only a few bands in the fingerprints (data not shown). Therefore, concentrations of genomic DNA extracts were carefully monitored by spectrophotometric determination at $260 \mathrm{~nm}$.

Species identification. On the basis of the AP-PCR fingerprints, 54 of the 57 field isolates were identified as belonging to one of the four species for which a reference strain was included in the studied sel (Table 1). Examples are shown in Fig. 2 to 4 . The remaining three New Caledonian strains (AQ114, W9, and W1) produced fingerprints unrelated to the AP-PCR patterns of the four type strains included in this study, were characterized by the complete absence of any species-specific amplicon, and, consequently, were not identified. For these three strains, phenotypic tests previously performed were in conclusive. Some highly conserved amplicons were found to be

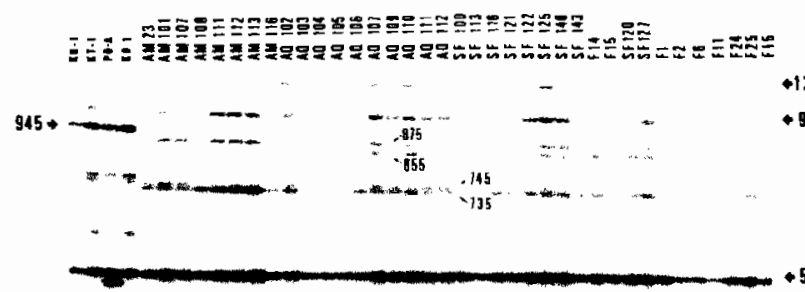

$+1235$

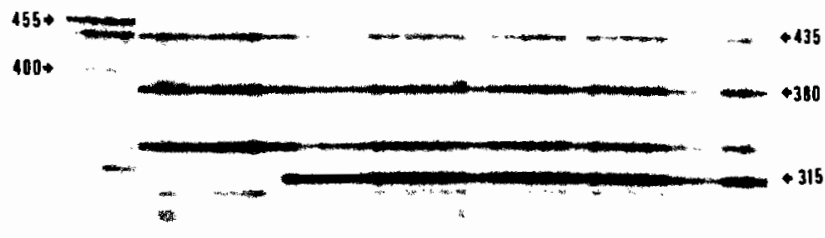

250

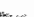

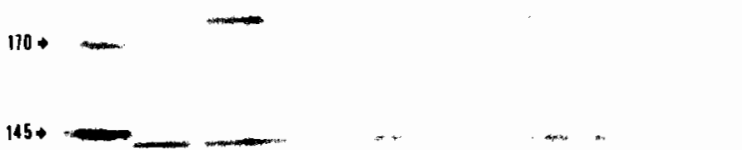

$+190$

FIG. 2. AP-PCR fingerprints of selected $V$. pencicicida strans produced with primer SP. Shown is an autoradiogram of a denaturing $5 \%$ acrylamide gel with TBE. The data for isolates in the upper part are given in Table 1. Molecular sizes (in base pairs) determined as described in Materials and Methods are given on the sides

genospecies specific. (i) With primer SP, $V$, penaeicida was characterized by 335-, 435-, 560-, and 985-bp fragmen1s, $V$. nigripulchritudo was characterized by $225-, 440-, 565-, 940-$, and 1,240-bp fragments, $V$. harveyi was characterized by $165-, 310$-, 365-, 510-, 745-, and 970-bp fragments, and $V$. alginolyticus was characterized by $230-, 595-$, and 745 -bp fragments (Fig. 2). (ii) With primer RSP, $V$. penaeicida was characterized by 160 210-, 215-, 405-, 770-, and 860-bp fragments, $V$. nigripulchritudo was characterized by $355-, 650-, 675-$, and 940 -bp fragments, $V$. haneyi was characterized by 150-, 195-, 205-, 270-, 295-, 355-, 365-, 450-, and 540-bp fragments, and $V$. alginolyticus was characterized by 225-, 275-, 450-, 480-, 525-, and 745-bp fragments (Fig. 3). (iii) With primer KF, V. penaeicida was characterized by $170-, 220-, 360-$, and 725 -bp fragments, $V$. nigripulchritudo was characterized by $215-, 250-, 400-$, and 825 -bp fragments, $V$. harveyi was characterized by $300-, 475-$, and 1,065 -bp fragments, and $V$. alginolyticus was characterized by $545-, 645-$, and 735-bp fragments (Fig. 4)

The New Caledonian Vibrio isolates were distributed among the four genospecies as following: isolates AQ61, AQ66, and SF5 were identified as $V$, alginolyticus, isolates AQ113 and W11 were identified as $V$. haneyi, and isolates AM102, AM109, AM114, AM115, SO27, SO38, and SO65 were identified as $V$. nigripulchriludo. The remaining 38 isolalcs were identified as $V$. penaeicida (as detailed in Table 1). The three Japanese isolates were confirmed to belong to $V$. penaeicida.

Intraspecies differences among $\boldsymbol{V}$. penaeicida strains. Comparative results are summarized in Table 2 . Japanese $\boldsymbol{V}$. penaeicida isolates could be discriminated from ones from New Caledonia by using each of the three primers. With primer SP, Japanese $V$. penaeicida strains were characterized by $145-$, 170-, 260-, 400-, 455-, 870-, and 945-bp fragments and New 


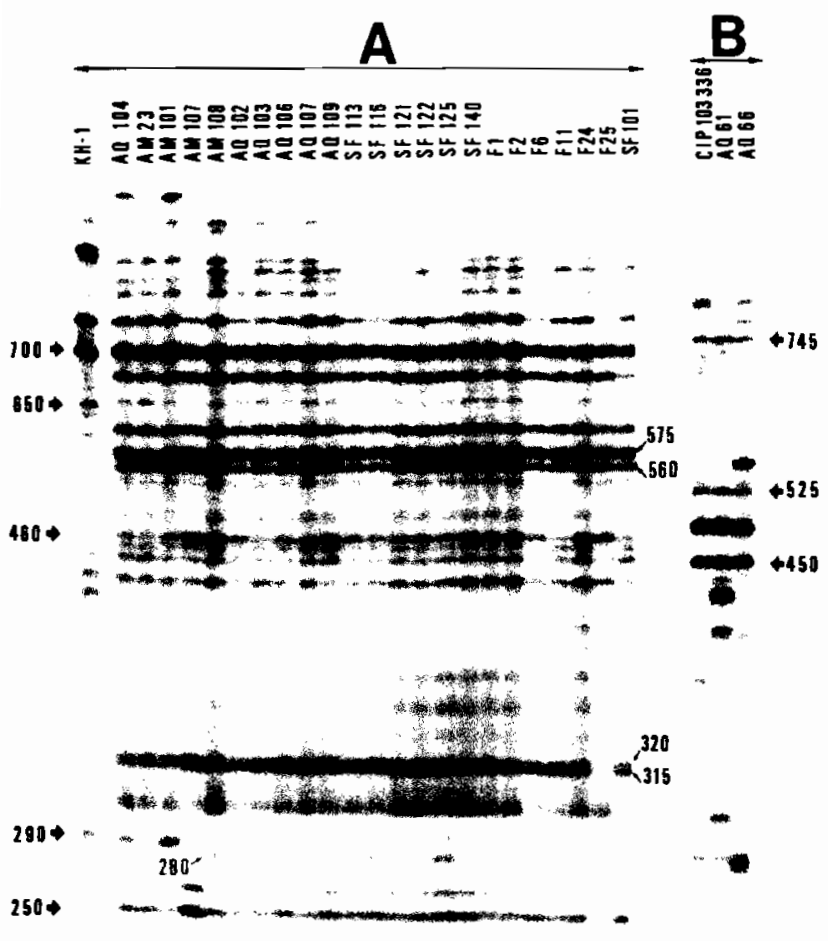

2084

160 FIG. 3. Autoradiogram with primer RSP. The lane assignments for isolates are given in Table 1. Molecular sizes (in base pairs) deter mined as described in Materials and Methods are given on the sides.

Caledonian ones were characterized by 140-, 190-, 280-, 285-, 380-, 735-, 745-, and 875-bp fragments (Fig. 2). With primer RSP, Japanese $V$. penaeicida strains were characterized by 185-, 280-, and 650-bp fragments and New Caledonian ones were characterized by 200-, 250-, 315-, 320-, 480-, 560-, 575-, 695-, and 700-bp fragments (Fig. 3). With primer KF, Japanese $V$. penaeicida strains were characterized by 210 - and 760 -bp fragments and New Caledonian ones were characterized by 340-, 400-, 790-, and 1,490-bp fragments (Fig. 4).

It was also possible to discriminate between the $V$. penaeicida isolates from New Caledonia. With primer SP, New Caledonian $V$. penaeicida was discriminated by $315-, 795-, 855-$, and 1,235-bp fragments; fingerprints of the strains originating from Aquamer were missing these fragments (Fig. 2). With primer RSP, New Caledonian $V$. penaeicida was discriminated by a 280-bp fragment; fingerprints of the strains originating from FAO, Aquamer, and SF101 were missing these fragments (Fig. 3). Lastly, with primer $\mathrm{KF}$, the additional presence of a 1,650-bp fragment allowed the individualization of FAO isolates and of 3 (SF101, SF126, and SF127) of the 11 Sea Farm

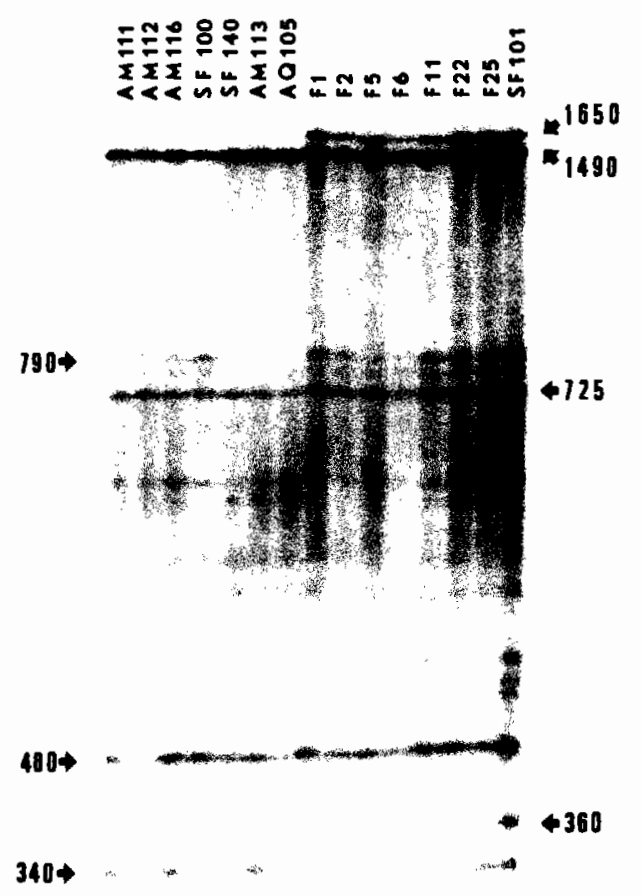

4220

$+170$

FIG. 4. Autoradiogram of AP-PCR fingerprints of selected $V$. penaeicida field isolates produced with primer KF. The data for isolates in the upper part are given in Table 1. Molecular sizes (in base pairs) determined as described in Materials and Methods are given on the sides.

isolates. This discrimination with primer $\mathrm{KF}$ was also possible by using the agarose gel-ethidium bromide technique.

\section{DISCUSSION}

Few researchers have used molecular biology tools for epidemiological studies on aquaculture-pathogenic marine Vibrio sp. isolates. Their genomic diversity was first investigated by using ribotyping $(2,22,29)$ or plasmid profiling $(10,22,26,29)$. However, if ribotyping is useful for taxonomic studies or subtyping, its discriminating power can be limited for studying population structures. Plasmid profiling can provide interesting results for Vibrio isolates, but the data obtained with this approach are limited to the extrachromosomal genome (15). Lastly, AP-PCR was recently demonstrated as useful for fast 
TABLE 2. Distribution of $V$. penaeicida field isolates according to the presence or absence of specific AP-PCR products obtained with primers SP, RSP, and $\mathrm{KF}^{a}$

\begin{tabular}{|c|c|c|c|c|c|}
\hline \multirow{2}{*}{ Isolatc (origin) } & \multicolumn{5}{|c|}{ Presence of fragment or fragment cluster: } \\
\hline & $A^{c}$ & $\mathbf{B}^{\prime \prime}$ & $\mathrm{C}^{\prime}$ & $\mathrm{D}^{\prime}$ & $E^{y}$ \\
\hline $\mathrm{KO}-\mathrm{I}(\mathrm{J})$ & + & - & - & - & - \\
\hline PD-A (J) & + & - & - & - & - \\
\hline $\mathrm{KT}-1(\mathrm{~J})$ & + & - & - & - & - \\
\hline $\mathrm{AM} 23(\mathrm{NC})$ & - & + & - & - & - \\
\hline AMI0I (NC) & - & + & - & - & - \\
\hline AM107 (NC) & - & + & - & - & - \\
\hline $\mathrm{AM} 108(\mathrm{NC})$ & - & + & - & - & - \\
\hline AMl11 (NC) & - & + & - & - & - \\
\hline $\mathrm{AM} 112(\mathrm{NC})$ & - & + & - & - & - \\
\hline $\mathrm{AM} 113(\mathrm{NC})$ & - & + & - & - & - \\
\hline AMI16 (NC) & - & + & - & - & - \\
\hline $\mathrm{AQ} 102(\mathrm{NC})$ & - & + & + & + & - \\
\hline $\mathrm{AQ} 103(\mathrm{NC})$ & - & + & + & + & - \\
\hline AQ104 (NC) & - & + & + & + & - \\
\hline AQI05 (NC) & - & + & + & + & - \\
\hline AQ106 (NC) & - & + & + & + & - \\
\hline $\mathrm{AQ} 107(\mathrm{NC})$ & - & + & + & + & - \\
\hline AQ109 (NC) & - & + & + & + & - \\
\hline AQI $10(\mathrm{NC})$ & - & + & + & + & - \\
\hline $\mathrm{AQ} 111(\mathrm{NC})$ & - & + & + & + & - \\
\hline $\mathrm{AQ} 112(\mathrm{NC})$ & - & + & + & + & - \\
\hline SF126(NC) & - & + & + & + & + \\
\hline SF $127(\mathrm{NC})$ & - & + & + & + & + \\
\hline $\mathrm{SF} 100(\mathrm{NC})$ & - & + & + & + & - \\
\hline SF113(NC) & - & + & + & + & - \\
\hline SF $116(\mathrm{NC})$ & - & + & + & + & - \\
\hline $\mathrm{SF} 121(\mathrm{NC})$ & - & + & + & + & - \\
\hline $\mathrm{SF} 122(\mathrm{NC})$ & - & + & + & + & - \\
\hline SF125 (NC) & - & + & + & + & - \\
\hline $\mathrm{SF} 140(\mathrm{NC})$ & - & + & + & + & - \\
\hline $\mathrm{SF} 143(\mathrm{NC})$ & - & + & + & + & - \\
\hline SF101 (NC) & - & + & + & - & + \\
\hline$F\rfloor(N C)$ & - & + & + & - & + \\
\hline $\mathrm{F} 2(\mathrm{NC})$ & - & + & + & - & + \\
\hline F5 (NC) & - & + & + & - & + \\
\hline F6 (NC) & - & + & + & - & + \\
\hline F11 (NC) & - & + & + & - & + \\
\hline F14 (NC) & - & + & + & - & + \\
\hline F15 (NC) & - & + & + & - & + \\
\hline F24 (NC) & - & + & + & - & + \\
\hline F25 (NC) & - & + & + & - & + \\
\hline
\end{tabular}

"The data for the isolates in the left column are given in 'Table $\mathrm{t}$

J. Japan; NC, New Caledonia.

Includes 145-, 170-, 260-, 400-, 455-, and 945-bp fragments obtained with primer SP, 290- and 650-bp fragments obtained with primer RSP, and 210- and 760-bp fragments obtained with primer $\mathrm{KF}$

'tncludes 140- 190- 280-, 285- 380-, 735-,745- and 875-bp fragments obtained with primer SP, 200-, 250-, 315-, 320-, 480-, 560-, 575-, 695-, and 700-bp fragments obtained with primer RSP, and 340-, 400-, 790- and 1.490-bp fragments obtained with primer $\mathrm{KF}$

Includes 315-, 795-, 855-, and 1,235-bp fragments obtained with primer SP.

A 280 -bp fragment obtained with primer RSP.

A 1,650-bp fragment oblained wilh primer $\mathrm{KF}$.

identification of species and strains of Vibrio (19) and another arbitrary amplification method, random amplification of polymorphic DNA (33), was shown to be efficient for the differentiation of the two biotypes of $\boldsymbol{V}$. vulnificus (2). Arbitrary amplification of DNA, which allows analysis of the whole genome, is considered a powerful approach for the study of DNA poly- morphism and is usable for the comparison of genomes from eukaryotes $(31)$ or bacteria $(25,32)$. In this case, AP-PCR can be used for species identification and provides information on intraspecific differences usable for molecular epidemiology studies $(25,32)$.

Analysis of AP-PCR fingerprints allowed us to categorize a significant set of Vibrio field isolates. The epidemiological approach of our study is original in that 35 of 53 field isolates were included on the sole basis of their isolation in high numbers in moribund-shrimp hemolymph during syndrome 93 mortality episodes without any previous analysis of these strains; the 18 others were previously studied by ribotyping (Table 1) (6). AP-PCR allowed identification to the genospecies level when fingerprints of field isolates were compared with those provided by reference strains of genospecies. In addition, complete agreement between AP-PCR and ribotyping data was observed. Fifty of the 53 field isolates were identified as belonging to one of the four genospecies included in the study. The three Japanese isolates exhibited AP-PCR fingerprints which were characteristic of $V$. penaeicida.

All isolates originating from the three mortalily peaks that occurred in 1995 were identified as V. penaeicida or V. nigripulchritudo, except two strains (one $V$. harveyi and one not identifiable). This observation confirms the major epidemiological role of these two genospecies in the pathogenesis of syndrome 93 and demonstrates that several Vibrio species and strains were implicated in the pathogenesis of this syndrome, indicating the importance of environmental factors and zootechnical practices. Although $V$. penaeicida was first described (13) in a shrimp vibriosis in Japan, this is the first report on the possible pathological role of $\boldsymbol{V}$. nigripulchritudo in marine aquaculture. The earlier role of $V$. alginolyticus and $V$. harveyi in the palhology could have been surpassed by the more pathogenic strains of $V$. penaeicida and $V$. nigripulchritudo (11). This hypothesis could explain the change in the infection pattern of Vibrio species involved in the outbreaks, with a major role of $V$. alginolyticus and $V$. harveyi in the initial episodes (1993 and 1994) followed in 1995 by the increasing impact of strains of $V$. penaeicida and $V$. nigripulchritudo.

The present study, conducted with a significant number of $\boldsymbol{V}$. penaeicida isolates, shows the heterogeneity of these strains according to their geographical origins, since AP-PCR fingerprinting allows clustering of isolates. At a first level, the discrimination between isolates originating from Japan and those from New Caledonia was readily possible whatever the primer used. At a second level, on the basis of the presence or absence of some fragments, the SP fingerprints of the $\boldsymbol{V}$. penaeicida strains isolated in New Caledonia were heterogeneous, with two distinct clusters. Similar results were observed with RSP and KF fingerprints. These two clusters were regarded as topotypes located $50 \mathrm{~km}$ apart on Saint Vincent Bay and Moindou Bay, as there was a perfect correlation between the geographical area of origin and a particular fingerprint. These two bays are quite different in ecology, so these two topotypes could have been selected during ecological adaptation to these two respective environments. Moindou Bay is relatively closed, with an important mangrove area, and is probably strongly influenced by aquaculture activities, whereas Saint Vincent Bay is a wide and open bay with few mangrove areas. Within the Saint Vincent Bay topotype, further discriminalion was possible that could not be attributed to any geographical, chronological, ecological, or zootechnical differences. However, these investigations would be deepened by phenotypic and virulence studies using representative strains from each cluster. Conversely, the $V$. nigripulchritudo fingerprints were homogeneous whatever the primers used, but these data have to be 
confirmed by studying a more comprehensive set of field isolates in order to investigate possible heterogeneity. The results of the present study demonstrate the practical value of this PCR-based strategy in studying marine Vibrio isolates for molecular epidemiology purposes. This approach may be applied to the analysis of other marine Vibrio strains, especially in aquaculture-pathogenic Vibrio species.

All isolates identified as V. nigripulchriludo originated from Sodacal and Aquamer, both of which are located on Moindou Bay. Therefore, it seems that pathogenic $V$. nigripulchritudo strains were absent from Saint Vincent Bay at the time of the survey. Despite numerous postlarval transfers between these two bays, there has been neither any contamination by pathogenic $V$. nigripulchritudo in Saint Vincent Bay nor any exchange of $V$. penaeicida topotypes between these two bays, confirming the absence of these pathogenic strains in postlarval stocks. At the time of the survey, both species and derived clusters could be considered geographically restricted. Considering the topotypes and the long persistence of $V$. penaeicida strains in seawater (9), it can be assumed that shrimp ponds were contaminated by the intake water pumped from the bays and that vibriosis must thus be considered a waterborne disease.

This should be confirmed by further ecological studies, but zoosanitary measures should already be taken to avoid possible dissemination of the pathogens. Therefore, shrimp farmers were advised against transfer of live shrimp between the different farms and hatcheries on the different bays. If transfer is necessary, the animals should be treated with antibiotics at the time of transfer, and the water used for the transfer should be sterilized by, as an example, chlorination-dechlorination methods.

Our results demonstrate the practical value of AP-PCR for studying marine Vibrio isolates for molecular epidemiology purposes. This approach may be applied to the analysis of other marine Vibrio species involved in mariculture pathology. The development of species-specific nonradioactive DNA probes derived from the highly conserved amplicons produced by AP-PCR (16) would simplify identification at the species or subspecies level. In addition, our field results emphasize the importance and the similarity of the respective virulence of $V$. penaeicida and $V$. nigripulchritudo isolates for $P$. stylirostris, concurrently demonstrated by experimental infection studies (11). As virulence plasmids have been reported in V. anguillarum, the agent of vibriosis in fish $(7,8,28)$, a study aiming to correlate virulence with the plasmid profiles of $V$. penaeicida and $V$. nigripulchritudo isolates is currently in progress in our laboratory.

\section{ACKNOWLEDGMENTS}

Thanks are due to Vincent Pomarède for technical assistance, to Eric Boglio for editorial advice, and the Territorial Laboratory of Veterinary Diagnosis of New Caledonia for maintaining and supplying the Vibrio field isolate collection.

This work was partly supported by grants from the South and North Provinces of New Caledonia. V. penaeicida $\mathrm{KH}-\mathrm{l}^{\mathrm{T}}$ and the three Japanese field isolates were kindly provided by K. Muroga (Faculty of Applied Biological Science, Hiroshima University, Higashi-Hiroshima, Japan). F.M. and P.P. were supported by the International Network of Pasteur Institutes (General Delegation, Institute Pasteur, Paris, France).

\section{REFERENCES}

1. Austin, B., M. Alsina, D. A. Austin, A. R. Blanch, F. Grimont, P. A. D. Grimont, J. Joffre, S. Koblavi, J. L. Larsen, K. Pedersen, T. Tiainen, L. Verdonck, and J. Swings. 1995. Identification and typing of Vibrio anguillarum: a comparison of different methods. Syst. Appl. Microbiol. 18:285-302. 2. Aznar, R., W. Ludwig, and K.-H. Schleifer. 1993. Ribotyping and randomly amplified polymorphic DNA analysis of Vibrio vulnificus biotypes. Syst. Appl. Microbiol 16:303-309.

3. Boom, R., C. J. A. Sol, M. M. M. Salimans, C. L. Jansen, P. M. E. Wertheimvan Dillen, and J. van der Noordaa. 1990. Rapid and simple method for purification of nucleic acids. J. Clin. Microbiol, 28:495-503.

4. Brenner, D. J., A. C. McWhorter, J. K. Leete Knuston, and A. G. Steigerwalt. 1982. Lischerichia vulnerix: a new species of Enterobacteriaceae associated with human wounds. J. Clin. Microbiol. 15:1133-1140.

5. Brock, J. A., and B. LeaMaster. 1992. A look at the principal bacterial, fungal and parasitic diseases of farmed shrimp, p. 212-226. In J. Wyban (ed.), Proceedings of the Special Session on Shrimp Farming. World Aquaculture Society, Baton Rouge, La

6. Costa, R., I. Mermoud, S. Koblavi, B. Morlet, P. Haffner, F. Berthe, M. I.egroumellec, and P. A. D. Grimont. 1998. Isolation and characterization of bacteria associated with Penaeus stylirostris disease (syndrome 93) in New Caledonia. Aquaculture 164:297-309.

7 Crosa, J. H., L. L. Hodges, and M. H. Schiewe. 1980. Curing of plasmids is correlated with an attenuation of virulence in the marine fish pathogen Vibrio unguillartum. Infect. Immun. 27:897-902.

8. Crosa, J. H., M. H. Schiewe, and S. Falkow. 1977. Evidence for plasmid contribution to virulence of the fish pathogen Vibrio anguiltarum. Infect. Immun. 18:509-513.

9. De La Peña, L. D., K. Momomaya, T. Nakai, and K. Muroga. 1992. Detection of the causative agent of vibriosis in kuruma prawn, Penatus japonicus. Fish Pathol. 244:223-228.

10. Giles, J. S., H. Hariharan, and S. B. Heaney. 1995. The plasmid profiles of fish pathogenic isolates of Aeromonas salmonicila, Vibrio anguillarum, and Vibrio orlalit from the Atlantic and Pacific coasts of Canada. Can. J. Microbiol. 41:209-216.

11. Goarant, C., and D. Saulnier. 1997. Unpublıshed data.

12. Grimont, F., and P. A. D. Grimont. 1987. Ribosomal ribonucleic acid gene restriction patterns as potential taxonomic tools. Ann. Inst. Pasteur/Microbiol. (Paris) 137B:165-175.

13. Ishimaru, K., M. Akagawa-Matsushita, and K. Muroga. 1995. Vibrio penaeicidla sp. nov., a pathogen of kuruma prawns (Penaets japoricus). Int. J. Syst. Bacteriol. 45:134-138.

14. Jiravanichpaisal, P., T. Miyazaki, and C. Limsuwan. 1994. Histopathology, biochemistry and pathogenicity of Vibrio harvcyi infecting black tiger prawn Penacus momodom. J. Aquat. Anim. Health 6:27-35.

15. Larsen, J. L., and J. E. Olsen. 1991. Occurrence of plasmids in Danish isolates of Vibrio amsuillanm serovars $\mathrm{O} 1$ and $\mathrm{O} 2$ and association of plasmids with phenotypic characteristics. Appl. Environ. Microbiol. 57:2158-2163.

16. Letocart, M. G. Baranton, and P. Perolat. 1997. Rapid identification of pathogenic Leptospira species (Leptospira interrogans, L. bongpetersenii, and L. kirschneri) with species-specific DNA probes produced by arbitrarily primed PCR. J. Clin. Microbiol. 35:248-253.

17. Lightner, D. V. 1988. Vibrio disease of penaeid shrimp, p. 42-47. In C. J. Sindermann and D. V. Lightner (ed.). Disease diagnosis and control in North American marine aquaculture. Elsevier, Amsterdam, The Netherlands.

18. Lightner, D. V. (ed.). 1996. A handbook of pathology and diagnostic procedures for diseases of penaeid shrimps. World Aquaculture Society, Baton Rouge, $\mathbf{L}$ a.

19. Martinez, L., S. Espelid, A. Johansen, J. Welsh, and M. McClelland. 1994. Fast identification of species and strains of Vibrio by amplification of polymorphic DNA. J. Fish Dis. 17:297-302

20. Mermoud, I., R. Costa, O. Ferré, C. Goarant, and P. Haffner. 1998. "Syndrome 93" in New Caledonian outdoor rearing ponds of Penaeus stvlirosiris: history and description of three major outbreaks. Aquaculture 164:297-309.

21. Mohney, L. L., and D. V. Lightner. 1994. An epizootic of vibriosis in Ecuadorian pond-reared Penaeus vannamei Boone (Crustacea: Decapoda). J. World Aquacult. Soc. 25:116-125.

22. Olsen, J. E., and J. L. Larsen. 1993. Ribotypes and plasmid contents of Vibrio anguillarum strains in relation to serovar. Appl. Environ. Microbiol. 59:3863-3870.

23. Pedersen, K., G. Ceschia, and J. L. Larsen. 1994. Ribotypes of Vibrio anguillentum O1 from Italy and Greece. Curr. Microbiol. 28:97-99.

24. Perolat, P., F. Merien, W. A. Ellis, and G. Baranton, 1994. Characterization of Lcptospira isolates from serovar hardjo by ribotyping, arbitrarily primed PCR, and mapped restriction site polymorphisms. J. Clin. Microbiol. 32: $1949-1957$.

25. Ralph, D., M. McClelland, J. Welsh, G. Baranton, and P. Perolat. 1993. L.cptospira species categorized by arbitrarily primed polymerase chain reaction (PCR) and by mapped restriction polymorphisms in PCR-amplified rRNA genes. J. Bacteriol. 175:973-981.

26. Sorum, H., A. B. Hvaal, M. Heum, F. L. Daae, and R. Wiik. 1990. Plasmid profiling of Vibrio salmonicida for epidemiological studies of cold water vibriosis in Atlantic salmon (Salmo salar) and cod (Gadus morhua). Appl. Environ. Microbiol. 56:1033-1037

27 Takahashi, Y., Y. Shimomaya, and K. Momomaya. 1985. Pathogenicity and characteristics of Vibrio sp. isolated from cultured kuruma prawns Penaeus iaponicus Bate. Bull. Jpn. Soc. Sci. Fish. 51:721-730. 
28. Tiainen, T. J. L. Iarsen, and S. Pelkonen. 1904 Characterization of Vibrio anguillarum strains isolated from diseased fish in Finland. Acta Vet. Scand 35:355-362.

29. Tiainen, T., K. Pedersen, and J. L. Larsen. 1995. Ribotyping and plasmid profiling of Vibrio anguillarum serovar $\mathrm{O} 2$ and Vihrio ordalii. J. Appl. BacIeriol. 79:384-392

30. Welsh, J., and M. McClelland. 1990. Fingerprinting genomes usıng PCR with arbitrary primers. Nucleic Acids Res. 18:7213-7218.

31. Welsh, .J., C. Petersen, and M. McClelland. 1991. Polymorphisms generated by arbitrarily primed PC.R in the mouse: applications to strain identification and genetic mapping. Nucleic Acids Res. 19:303-306.

.32 Welsh, J., C. Pretzman, D. Postic, I. Saint Girons, G. Baranton, and M. McClelland. 1992. Genomic fingerprinting by arbitrarily primed polymerase chain reaction resolves Borrelia hurgdorferi into three distinct phyletic groups. Int. J. Syst. Bacteriol 42:370-377.

33 Williams, J. G. K., A. R. Kubelik, K. J. Livak, J. A. Rafalski, and S. v. Tingey. 1990. DNA polymorphisms amplified by arbitrary primers are usefu? as genetic markers. Nucleic Acids Res. 18:6531-6535. 
